\title{
The influence of website characteristics on customer satisfaction and E-WOM in Indonesia
}

\author{
Alldila Nadhira Ayu Setyaning ${ }^{*}$, Sahid Susilo Nugroho ${ }^{2}$ \\ ${ }^{1}$ Faculty of Business \& Economics, Universitas Islam Indonesia, Yogyakarta, Indonesia \\ ${ }^{2}$ Faculty of Economics \& Business, Gadjah Mada University, Yogyakarta, Indonesia \\ ${ }^{*}$ Corresponding author: 193110102@uii.ac.id
}

\begin{abstract}
There are many retailers that have developed their web stores and online forums with the purpose of getting closer to their customers. However, the significant growth of online stores makes the e-retailers face a challenge of fierce competition and survival. This study aims to analyse the relationship of website characteristics on customer satisfaction and positive E-WOM in internet shopping in Indonesia. The quantitative method is used to determine the relationships among variables. This research analysed 340 respondents who are born between 1984 to 2002 that have been experienced in buying the product from e-retailer in Indonesia at least once a month during the last year. To collect the data, this research used convenience sampling. The researcher used an online survey by Google Form to spread the questionnaires. Structural Equation Model with AMOS program was conducted to test the hypotheses. The results show that not all hypotheses are supported. The influence of shopping convenience on customer satisfaction and the influence of informative on customer satisfaction is positive but not significant. This research could help the e-retailers by providing digital marketing information, specifically, about attributes in website characteristics that could influence E-WOM through customer satisfaction.
\end{abstract}

Keywords: website characteristics, customer satisfaction, e-trust, e-commitment, E-WOM

JEL Classification Code: M31

DOI: $10.20885 /$ jsb.vol24.iss2.art5

\section{Introduction}

In this digital era, society cannot be separated from technology and the internet. Along with the development of technology, the internet has a shift in the way it functioning. It is not only used for the media to send an email or social media, but it also has started to become a platform where people could seek information about products or services they would like to purchase. Marketers do not only try to gain the number of purchasing and customer satisfaction, but they also seek for the long-term relationships with their customers (e.g. trust, commitment). According to Murphy and Sashi (2017), there is a meta-analysis of satisfaction that shows the relationship of satisfaction drives trust, trust drives commitment. At this stage, trust and commitment can enhance positive word-of-mouth (WOM) which positively gives an impact on the acquisition of new customers (Chung \& Shin, 2010). HennigThurau, et al. (2004) explained e-WOM as a positive or negative statement made by the customer toward certain product or company which is made for public in the internet. Word-of-mouth communication in online environment can affect more people during a short period of time. Thus, since WOM is very important in e-commerce, to obtain commercial success. The marketers should understand the strategic implications contributing to the relationship quality, especially those that could contribute to the electronic word-of-mouth communication. Chung and Shin (2010) proposed five factors included in the website characteristics which have positive effects on customer satisfaction, they are shopping convenience, website design, informativeness, security and communication.

Srinivansan, et al. (2002) stated that shopping convenience positively influence customer satisfaction. Online customers expect a fast and efficient purchasing process. A website that is able to provide a shopping convenience to its customers will minimize the customers to make mistakes and will generate a satisfying shopping convenience. A company that is providing a high-quality service 
in creating a shopping convenience will results in satisfied user, thus, affects a firm's growth. Wang, et al. (2010) stated that aesthetic aspect of the website may be influential on customer satisfaction. They might feel pleasant in a good appealing because it can improve their satisfaction in shopping experience. Liu, et al. (2008) stated that quality of the information significantly and positively influences customer satisfaction. A clear, managed, and organized website is the reflection of the providers' effort in providing availability to customer's information processing and it positively affects consumer satisfaction. Fullerton (2011) mentioned that security practices positively influences customer satisfaction as well. The users started to be more aware of the significance of the information security as they are engaged in the safety behavior in using online platform. They also believed that communication positively influences customer satisfaction. The communication activity enable the customers and the e-retailer providers to share expectations over time. A study from Horppu, et al. (2008) stated that customer satisfation positively influences customer trust. They mentioned that customers who satisfy with the online service provider, they are more likely trust to the company. A literature proposed by Cater and Zabkar (2008) believed that there is a positive effect of customer satisfaction on e-commitment. They found that commitment plays a significant role in generating and maintaing the long -relationship between the buyers and the sellers. Based on Chung and Shin (2010), e-trust has a positive relationship to e-commitment. There is no commitment without trust. Consumers are more willing to commit to a company when they have a strong belief in its relationship. Consumer commitment can predict the customer retention, such as switching/staying intentions or repurchase intention. (Horppu, et al., 2008). It is expected that when customers trust to the e-retailer, they are most likely to commit to their relationship with the company. A study from Mukherjee and Nath (2007), mentioned that trust significantly and positively influences positive e-WOM. In the online retailing context, trust plays a big role in order to generate the transaction. Tsao and Hsieh (2012) has stated that e-commitment positively influences word-of-mouth communication. When the level of commitment increases, customers obtain a greater comprehension of what is expected of them during the exchange process.

The growth of internet usage penetration in Indonesia increased to 143 million people or equal to 54.7 percent of the total population (APJII, 2017). The increasing number of users accessing the internet affects communication availability, as well as the scope of electronic commerce. According to a survey conducted by Indonesia Internet Service Provider Association/ APJII (2017), there are 82.2 million users or 62 percent of internet users access online shopping in Indonesia and it is projected to be one of the largest e-commerce markets in Asia, with the value of e-market at 130 billion USD by 2020. Seeing the enthusiasm of Indonesian who are interested in internet shopping, those online store companies are increasingly trying to adjust their strategy following the demands and needs of consumers that shop via online. Competitiveness in e-commerce is only a few clicks away. It leads the customers to compare the competing products and services with only small effort. The rapid development of the online retailing stimulates consumers to be more anticipative in purchasing products. The ability to speak candidly can result in some issues for online customers, such as difficulties to distinguish what is correct and incorrect information and catch criminals. Retailers find it as important considerations on e-commerce, in which, shopping through the website is very tricky rather than shopping in an offline store that has been physically stepped in (Hennig - Thurau, et al., 2004). In line with the significant growth of the online stores, Indonesian retailers face a challenge of fierce competition and survival. With the ability to deliver information very quickly at no cost, the high speed of the exchange of the information leads to the creation of a highly competitive in the market, both locally and internationally. Also, the issues regarding to satisfaction, trust and commitment have raised in importance in the online context.

Previous study conducted by Chung and Shin (2010) mentioned that the website characteristics are found to be related to customer satisfaction in South Korea. They find that communication of website characteristics influences customer satisfaction more than the other factors. There is still less of empirical research in relationship quality of online retailing, especially in Indonesia. There are a 
few focuses on customer satisfaction and e-trust, and do not include e-commitment (Chung and Shin, 2010; Choi et al., 2007). There were significant differences in internet innovativeness and perceived risks of internet shopping, but no significant difference in internet buying intention between South Korean users and Indonesian users (Chung and Shin, 2010; Dharmesti, M.D.D and Nugroho, S. S. 2013). In addition, there are only a few studies analyzing the relationship of e-trust, e-commitment, and e-WOM. Meanwhile, e-WOM is perceived as a significant form of promotion, where trust plays the critical role. Therefore, it is important to identify the relationship quality of e-retailing in Indonesia.

This study will analyze the relationship of website characteristics on customer satisfaction and positive E-WOM in internet shopping in Indonesia. By determining the relative importance of the website characteristics on positive E-WOM in online retailing in Indonesia, this research could help the retailers by providing the digital marketing information, specifically, about what attributes in website characteristics that could enhance e-WOM through customers' satisfaction. The website characteristics are included shopping convenience, website design, informativeness, security, and communication. It is important to build relationship quality (customers' satisfaction, e-trust, and e-commitment) in internet shopping in spite of pursuing the long-term beneficial relationship with the customer. It is expected that this study can show the relationship between those factors in order to stimulate positive e-WOM from the customers.

\section{Literature Review}

\section{Website Characteristics}

There are many elements of a website can attract its customers. Hidayat, Saifullah and Ishak (2016) described website characteristics as a whole impression of a user about the website attributes in terms of information, system, and service quality. Another literature mentioned that character can be described as a whole e-retailer's personality or image that is projected to consumers through the text, style, graphic, or color of the website (Srinivansan, Anderson, \& Ponnavolu, 2002).

Website developers and business practitioners have determined the instruments for measuring the usability of their websites; however, there are still no exact tools that can measure it. Website usability can be seen from how accessible the website is, how effortless for the users to explore the website and how engaging the website is (Tarafdar \& Zhang, 2005). It is very important because the high usability will result in high online transactions. On the other hand, a website with poor design will lead to negative feedback of the users. Consumers are likely to allocate less time to do shopping and more to other activities. Their need for convenience and shortens the time has shifted to go shopping at a virtual shopping store as an alternative media rather than go to offline store. It is essential for the online retailers to develop the online shopping convenient, which are maximizing the speed and ease of shopping (Jiang, Yang, and Jun, 2012).

This issue has took the attention of many researchers to develop the methodology to measure the overall website characteristics. Hidayat, et al. (2016) developed a website measurement tool that consist of five elements: (1) homepage; included the main components of the website; (2) website design; included the ease of navigation, access speed, response time, and data security; (3) content; as the information need to be updated; (4) audio-visual elements; included text, graphics, audio or video; (5) interaction; a response to customers order via electronic mails, chats, or surveys. According to Loiacono, Watson, and Goodhue as cited in Chung and Shin (2010), there are 12 dimensions that measures the website characteristics, which are informational fit-to-task, interactivity, trust, time to response, ease of understanding, immediate operations, visualization, innovativeness, emotional appeal, consistent image, integrity and better than other channels. Palmer (2002) find other 12 dimensions to measure the website interface: ease of use, aesthetic design, processing speed (responsiveness to customer order), and security of financial and personal information. Szymanski and Hise (2000) proposed four attributes that affect customer satisfaction on website: consumer perceptions of convenience, product information, website design, and financial security. 
The result of those website characteristics identifications has brought Chung and Shin (2010) to analyze five attributes considered as the most important of website characteristics to consumers: shopping convenience, website design, informativeness, security, and communication. Generally, shopping convenience can be described as the intention of consumers to enjoy online shopping, to which consumers feel that the website is interesting and easy to navigate (Chung \& Shin, 2010). Design of the website is a representation of physical store environment which may affect the customer's perception of the store (Wang, Hernandez, \& Minor, 2010). According to Jiang, et al. (2012), the clear information regarding to the product specification is very important to be displayed when the customers visit the website. According to Chung and Shin (2010), security can be described as the protection of privacy that is considered to be the most important issue to increase the trustworthy. The security in online transaction and the protection of personal information are very crucial in online purchasing system (Szymanski \& Hise, 2000). They mention that a positive perception of financial security positively affects customer satisfaction level in online environment. Perceived security risk and privacy is the determination of service satisfaction in e-commerce (Chung \& Shin, 2010). Virtual community becomes a platform for the online users to communicate to each other, seek for information, and exchange the opinion. Chung and Shin (2010) also stated that customer service is one of the key drivers of online customer trust. Therefore, communication factor is included in online attribute.

\section{Customer Satisfaction}

Customer satisfaction has become an essential topic in e-marketing field for so long. Fullerton (2003) pointed out that customer satisfaction is an important assessment of the relationship between website users and service providers. According to Saleem, et al. (2017), they defined customer satisfaction as belief that provides security to the customers' that their interest is protected. A well-designed website can captivate online customers that can result a satisfaction to the service providers. Palmer (2002) found that design metrics for website, content, and navigation are significant to a website success. In other research, the website design and ease of use is an income to customer satisfaction (Szymanski $\&$ Hise, 2000). Derived from the conceptualization developed by those researchers, customer satisfaction depends on several elements, including web design, content, display, navigation, and structure of information provided (Chung \& Shin, 2010). Balasubramanian, Konana, and Menon (2003) defined satisfaction in the website refers to an enjoyment to online experience, including access to information, ease of website navigation, and perception of website design.

In the electronic service context, the ease of navigate the website and its perceived value, such as shopping convenience, website design, informativeness, security, communication, will affect customer satisfaction (Chung \& Shin, 2010). A website that is convenient to operate will minimize the customers to make errors and will generate a more satisfying shopping experience. This theory is supported by the previous studies as follows: Srinivansan, et. al. (2002) believed that the greater the convenience, the greater the satisfaction of its customers. A website that is convenient to use will reduce the customer fraud and will make their shopping experiences more satisfying. They believed that online customers expect a fast and efficient transaction process. If they feel that they give too much effort in execute transactions, they are less likely to come back. Another literature from Jiang, Yang, and Jun (2012), empirically find that convenience has a significant effect on customer's satisfaction. They stated that shopping convenience in a website is considered as a crucial point of departure for online retailers to maximize the speed and ease of shopping itself. The finding indicates that a company that is providing a high-quality service in creating a shopping convenience will results in satisfied user, thus, affects a firm's growth. The more convenience that is perceived on the website, the greater the customer satisfaction will be obtained. Website display is the first appearance that customer can see and access based in a product they are willing to purchase, therefore, website design is strongly related to the customer perception toward the company (Wang, et al., 2010). They stated that when customer deals with purchasing process, aesthetic will be influential on customer satisfaction. On the other hand, when customers are dealt with an e-retailing web website without 
purchasing tasks, aesthetic will not significantly effect customer satisfaction. Customers usually feel pleasant in an aesthetic appealing of the website because their shopping experience is improved by the highly appealing environment.

A study from Ponnavolu as cited in Chung and Shin (2010) stated that a well-designed website (interactive color, graphic or website theme), will lead to the great satisfaction of its customers. A design of website might result the positive outcome to online satisfaction. This statement is supported by Szymanski and Hise (2000), in which they stated that website design is considered as one of the greatest effects on online satisfaction. They found that consumer satisfaction with a retailing web website will rise if the website is more organized. Park and Kim (2003) found that the quality of user interface affects the customer satisfaction as it provides the physical evidence from the providers as well as facilitating the effortless use of its service. They said that the satisfied online users came from the great appealing website. The greater the display of a website, the greater the customer satisfaction will be obtained.

Shankar, Smith, and Rangaswamy (2003) noted that the ease of information has a positive impact on customer satisfaction in electronic service. They stated that the information disclosure influences more on the overall customer satisfaction when the service is done by online than offline. Another study from Liu, et al. (2008) stated that the information quality has a great effect on customer satisfaction as well. Additional information will enhance the quality of options that customer makes, which in turn, is resulted in an experience that creates higher satisfaction when choices are made. If the websites have more information (including visual information), it will result in greater satisfaction. A clear, managed, and organized website is the reflection of the providers' effort in providing availability to customer's information processing and it positively affects consumer satisfaction. This information quality is considered as one of the characteristics of website quality, in which it has the ability to give an positive and significant impact on customers satisfaction (Chung \& Shin, 2010). It has been known that a service provider's effort in assisting consumer's information processing and decision making positively affect satisfaction of the customer. Customers who are involved in online purchasing process are more concerned about the product information in order to generate the purchasing decision. Therefore, the higher the ease of obtaining information, the higher the customer satisfaction that is obtained.

There are some of studies have analyzed the relationship between security and customer satisfaction, both in offline and online environment. As the development of the technology, people perceived security risk and privacy are important as the indicator of e-commerce service satisfaction. The users started to be more aware of the significance of the information security as they are engaged in the safety behavior in using online platform. Security is an important factor in acquiring and retaining online shopping customers. This statement is supported by the study conducted by Fullerton (2011), he mentioned that the satisfaction of the users are strongly related to the information security practices. Another research stated that one of the factors that is influencing customer satisfaction in online environment is security (Park \& Kim, 2003). They mentioned that customers care about online payment security, reliability, and privacy policy of the online store. Based on study conducted by Szymanski and Hise (2000), a positive perception of financial security influences online customer satisfaction. As perception of security risk declines, they believe that the satisfaction of online stores will increase. The more secure the website, the more customers feel satisfy toward the company.

Buyers and sellers are able to share their expectations through communication process. According to Chung and Shin (2010), satisfaction of buyer-seller relationships are the consequent of multiple evaluations of people, event, and object that is related to the communication among them. A study proposed by Murphy and Sashi (2018) mentioned that there is the effect of communication on customer satisfaction. Buyer satisfaction mediated with technology communication from the seller (e.g. e-mail, voice mail, FAQ) has been recognized to have positively significant effect on future purchase intention. It is important to support communication both for the customers and the vendors. As the vendors, they have to provide a good communication system and give the space for their 
customers to be able to exchange opinions in the website. As the increasing of the effectiveness in communication, the relationship conflict would be decreased. This statement is proposed by Fullerton (2011), they believed that communication influences positively on the whole satisfaction. The communication activity enable the customers and the e-retailer providers to share expectations over time. Satisfaction in these relations of buyers and sellers are the outcome of multiple evaluations of events, people, and objects related to the exchanges information between buyer-seller. At this stage, communication may have a positive impact on satisfaction. As the level of effective communication rises, the conflict that may give a negative impact on customer satisfaction will decrease. In other words, the more the website can facilitate communication with the customers, the more they will satisfy to the website. Therefore, the following hypotheses can be proposed:

H1: Shopping convenience positively influences customer satisfaction.

$\mathrm{H} 2$ : Website design positively influences customer satisfaction.

H3: Informativeness positively influences customer satisfaction.

H4: Security positively influences customer satisfaction.

H5: Communication positively influences customer satisfaction.

\section{E-Trust}

Trust in online environment has become popular along with the increasing of the transaction in ecommerce. As a traditional form of E-trust, trust means an intention that reflects the confidence on something that includes uncertainty and vulnerability factors (Hidayat, et al., 2016). According to Kim and Park (2013) online store's trustworthiness is the most important elements in online shopping. It is because in the digital business consumers have to deal with the absence of face-to-face contact with the sellers. The customers obviously prefer to purchase the product/service from online vendors that they can trust. The information towards brands, products, or companies shown in the suggestion columns indicate that the level of trust is high in that particular form, which means that the information is at the most popular searches on the internet.

In the digital context, the presence of something to rely on is important because it will decrease the risk to trust the other party. In the online environment, there are several factors absent in the trust, such as physical appearance, the distance between the sellers and the buyers, absence of a salesperson, online payment systems, etc. It makes a concern for customers to re-evaluate the sellers. At this stage, the sellers need to raise the consumers' trust to decrease the perceived risk as it may affect to the purchase intention. Factors absent in the E-Trust can reduce the consumer confidence of the seller and will lead consumers to not purchase the product. Generally, it is difficult to gain trust from customers, therefore, E-Trust becomes the important variable in this study.

Customer satisfaction is strongly related to how customer perceived value from products or services. In e-marketing context, trust is hard to be separated from customer satisfaction (Chung \& Shin, 2010). Choi, Choi, and Lee (2007) proposed that a high level of satisfaction in online transaction plays a role to raise the consumer trust. They agreed that web website trust develops through the customer satisfaction based on his/her experience.

According to Martinez (2015), trust is related to satisfaction. Another study also showed that e-satisfaction positively and significantly influence e-trust (Horppu, Kuivalainen, \& Ellonen, 2008). They mentioned that e-commerce providers should put greater attention about enhancing service quality because the more customer satisfy with the products and services, the more they will trust to the company. They empirically proved that there is a positive relationship between web website satisfaction and trust. Customer satisfaction is perceived as an essential concept as it seems to be a requirement for web website trust and loyalty. The higher the level of online customer satisfaction, the higher the level of customer trust will be obtained. After discovering in previous literatures on relationship between customer satisfaction and e-trust, then a hypothesis can be proposed:

H6: Customer satisfaction positively influences e-trust. 


\section{E-Commitment}

Customer commitment plays a role in the long-term relationship. It is managed through the reasoning of mutual trust. According to Tabrani et al. (2018), commitment can be defined as a customer's feeling of attachment and belongingness with certain companies. Many researchers and practitioners agree that build long-term relationships with customers will gain positive returns to the companies. Mostly, commitment has been found as the instrumental in brick-and-mortar exchange relationship, therefore, the lack of literature in customer e-commitment toward e-retailers needs more additional empirical researches. Researchers nowadays has identified that commitment is a strong tool to predict the various metrics related to customer retention, such as switching/staying intentions and repurchase intention (Hidayat, et al., 2016).

In the online context, e-commitment means a feeling of connection that reflects the sense of ownership and encouragement in e-commerce (Fullerton, 2011). Another literature written by Lin and Luarn as cited in Chung and Shin (2010) also mention e-commitment as a psychological feeling to service in electronic service that is shaped before the customer can decide the repurchase behavior. Therefore, commitment can be seen as the continual relationship factor between the buyers and the sellers. It is expected that when the buyers perceived justice regarding of the interaction along with the service process, they are inclined to manage the relationship.

In the study written by Cater and Zabkar (2008), they found that commitment is a key component of generating and maintaining long-term relationship between the buyers and the sellers/affective commitment. They found that there is a positive influence of satisfaction on commitment. Together, satisfaction and commitment positively affect the behavioral intention, such as WOM communication, purchase intention, and continued interaction (Mukherjee \& Nath, 2007).

Another study from Fullerton (2011) supports that there is a positive and significant relationship between satisfaction and affective commitment. The relationship with a high satisfaction firm is more motivated to continue the relationship. Customers feel satisfy when they have great overall experiences with certain providers, thus, they would like to feel that they should stay with that company because of the service that the company has done for them. In the service context, the greater the customer satisfaction toward the service experience, the greater they are likely to commit to a relationship with the provider.

In the online retailing context, trust is considered as an essential component to generate the transaction. Therefore, it is so obvious that customers will prefer to buy products in the trusted eretailers. Some authors have analyzed that trust positively influence commitment in B2C context (Horppu, et al., 2008). Trust is resulted from a past activity and makes a customer to think about future and become committed to a certain company or brand. A customer will become committed to a provider that they can put trust on it. When there is a high trust in a relationship, it means that the customers will continue the relationship because he/she likes the firm and enjoy working with them. On the other hand, when the trust is low, it is the stage where a company should examine and monitor the behavior of the counterparts.

Another study conducted by Mukherjee and Nath (2007) mentioned that e-trust has a positive relationship to e-commitment. When customer trust is increasing, company would feel a sense of moral obligation to not disappointing their customers. It also means that the more customer trust to the companies, the more they feel to continue the relationships. According to Chung and Shin (2010), e-trust and customer satisfaction are the antecedents of commitment. They found that more satisfied customers stay on a certain provider because they trust the firms and enjoy the purchasing experiences. Therefore, the more customers put trust on the e-retailer, the more they would likely to commit to their relationship with the vendors. Hence, the following hypotheses can be generated:

H7: Customer satisfaction positively influences e-commitment.

H8: E-trust positively influences e-commitment. 


\section{Positive E-WOM}

Day-by-day, the use of e-WOM is rising as well as the increasing number of consumers that are shopping through online stores. Some consumers not only use a single platform but rather some of alternative in different types of platforms. Those online platforms have become a place for consumers to discuss and share the information about the product they interested in. E-WOM is described as a statement, positive or negative, made by a customer about the products or the company which is made to public via the internet (Hennig-Thurau, et al., 2004). It can be created by consumers and vendors. Hsu, Wang and Chih (2013) stated that positive e-WOM will increase customers' confidence and decrease the risk and affect their purchase behavior. A study conducted by eMarketer (2008) shows that there are about 60 per cent of consumers look for e-WOM before purchasing products and consumers who are only willing to buy online after reading others' reviews are about 80 per cent.

Recently, it can be seen that there are many digital-based companies try to attract their customers through social media or websites (Hajli \& Sims, 2015). A study proposed by Liang and Tuban (2011) has confirmed that word-of-mouth communication and the activities involved in social networking sites are greatly affecting consumer decisions. Some of current researches shown that more and more consumers gradually perceive social networking sites as a tool of e-commerce with the purpose to gain information about the products in the market (Barreda, Bilgihan, Nusair, \& Okumus, 2015). Therefore, companies at this stage might benefit from positive e-WOM as the consumers continuously share the information about their products, which it may influence other people's intentions as well.

The customers are willing to read other people reviews because there is increasing trust among the users (Smith \& Adviser-Menon, 2002). Nowadays, it can be seen that a number of consumers who publish their reviews on the internet is increasing significantly. According to HennigThurau, et al. (2004), they stated that e-WOM significantly influences several individual levels, included the level of trust. In online context, trust increases the buyers' willingness to repurchase the products and reduces the desire to spread negative review to other people (Barlow, et al., 2004).

Another literature mentioned that customer trust in the website is positively associated with the customer engagement in positive e-WOM (Mukherjee \& Nath, 2007). It means that the more customers trust to the company, the more they will spread positive e-WOM. When a customer gives a recommendation to others about a product reputation in a virtual community, he/she may simultaneously have a higher level of trust to the seller. It explains about how customers can easily trust and accept the other people recommendations. The writing expresses in online environment may affect consumers' trust and their willingness to buy and pay the premium price (Hennig-Thurau, et al., 2004). The more customer trust to the website, the more they would like to recommend to others.

Several studies have examined what leads to electronic-word of mouth, included the influence of commitment on positive e-WOM. Tsao and Hsieh (2012) have stated that e-commitment has positive effect on WOM. They believed that customers with high search intention for information of the product in online store are more likely to have high intention to give recommendation to other people, compared to others who have lower search intention. A study from Chung and Shin (2010) said that to reduce perceived risks, consumers often depend on other people's reviews. If commitment to the company is high, positive WOM is more likely.

Another research proposed by Wulf et al. (2006) stated that customers who commit to a certain service provider will typically show high purchase intentions and are more willing to give recommendation to others. They mentioned that committed customers typically show higher purchase intention, are more willing to pay the higher price, and are more willing to give recommendation to other customers. The higher the customer commitment, the more customers will engage to the online activities to share information, share opinions, and recommend that provider to other online customers. Thus, the hypotheses can be proposed as:

H9: E-trust positively influences positive e-WOM.

H10: E-commitment positively influences positive e-WOM. 


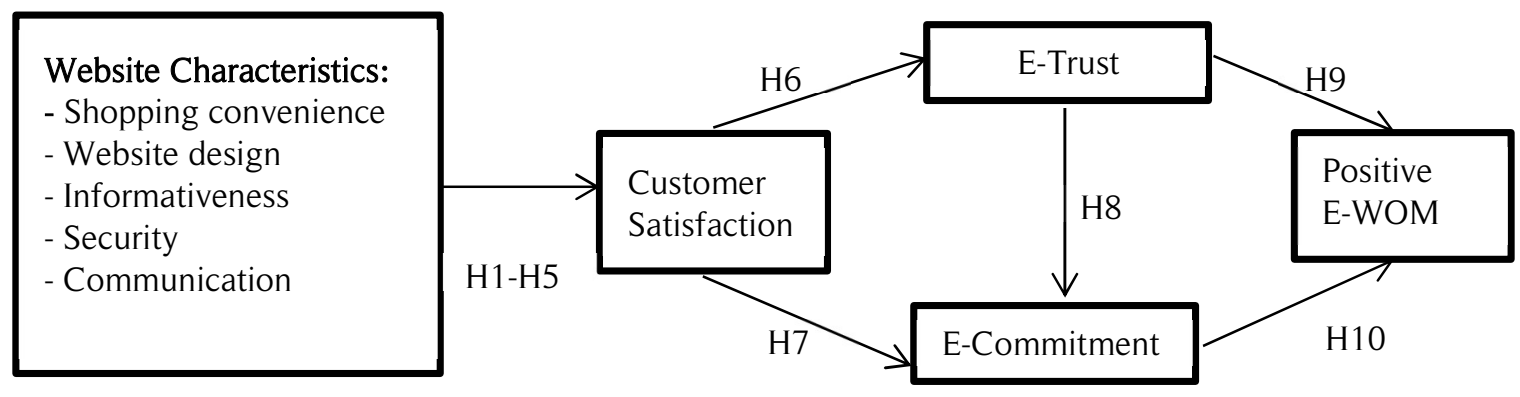

Figure 1. Research Model

\section{Research Methods}

The approach used in this research is a quantitative method. This method is used to determine the influence of website characteristics on customer satisfaction and positive e-WOM in internet shopping. This study is conducted in Indonesia with the population of this research is Indonesian, both male and female. The sample of this study are born between 1984 to 2001 and frequently access to the internet. The respondents are the internet users who have experienced in buying product via online at least once in a month during the last one year. According to Bolton, Hoefnagels, Migchels, Kabadayi, Gruber, Loureiro and Solnet (2013), Millennials or Gen Y is the generation who are living with the entire digital environment. This generation are born between 1978 - 2002 and have a way of live that is significantly affected by the technology. Gen $Y$ has the characteristics which are well educated, skilled in technology, have desire for speedy advancement, and need for more social interaction.

This research used convenience sampling method, which the technique is chosen as it is the fastest method due to the limited period of time. The questionnaires are gathered by the help of Google Form to get more geographical coverage. The questionnaire is translated in Bahasa Indonesia to be understood by the respondents. It has 34 question items, in which each item is measured by using seven-point Likert scale, from strongly disagree (1) to strongly agree (7). The data $(n=340)$ are collected from Indonesian online shopping users who have experienced in purchasing product from Indonesian online shopping websites.

Customer loyalty, e-trust, and e-commitment are the mediating variables that connect the independent variables, which are shopping convenience, website design, informativeness, security, and communication, with the dependent variable, positive e-WOM. Thus, the operational definition and measurement in this research are explained as follow:

1. Shopping Convenience

Shopping convenience can be described as consumer perception concerning to what extent the website can make consumers enjoy to shop, and feel that the web website is easy to operate. In determining the parameters of this variable, it will be measured using items adapted by Chung and Shin (2010). The four questionnaire items are: 1) I feel this website is very convenient to use. 2) I feel it takes a short time to shop at this website. 3) I feel this website provides ease procedures of ordering. 4) I feel that a first-time buyer can make a purchase from this website without much help.

2. Website Design

Website design explains consumer evaluation concerning to what extent the composition of display, layout, function and symbol on a website can represent a store environment that influences his/her perception toward the physical store as a whole. In determining the parameters of this variable, it will be measured using items adapted by Chung and Shin (2010). The four questionnaire items are: 1) I feel that this website is visually appealing. 2) I feel that this website 
has good selection. 3) I feel that the website's appearance is professional. 4) I feel that it is quick and easy to complete a transaction at this website.

\section{Informativeness}

Informativeness refers to consumer perception towards the ease of information about product specifications in the website. In determining the parameters of this variable, it will be measured using items adapted by Chung and Shin (2010). The four questionnaire items are: 1) This website provides the rich information on features and quality of the products. 2) This website provides the accurate information on features and quality of the products. 3) This website provides various kinds of peripheral information (payment, delivery, and return). 4) This website provides the good information of products.

\section{Security}

Security explains to consumer evaluation concerning to what extent the web website can protect consumer privacy that influence their perceptions to increase the trustworthiness. In determining the parameters of this variable, it will be measured using items adapted by Chung and Shin (2010). The four questionnaire items are: 1) I feel safe in my transactions with this website. 2) I feel like my privacy is protected at this website. 3) I trust this website will not misuse my personal information. 4) I trust this website will not give my information to other sites without my permission.

5. Communication

Communication in the virtual community refers to the consumer evaluation concerning to what extent the attributes of the website can facilitate the users to seek out social contact in the retail settings. In determining the parameters of this variable, it will be measured using items adapted by Chung and Shin (2010). The four questionnaire items are: 1) I feel free to say about an idea/or complaint at this website. 2) I feel this website has good FAQ system. 3) I feel I can actively review products of this website. 4) I feel this website provides free to exchange opinions between customers.

6. Customer Satisfaction

Customer satisfaction is a customer evaluation concerning to what extent various outcomes and experiences of the product in the online store can satisfy his or her. In determining the parameters of this variable, it will be measured using items adapted by Chung and Shin (2010). The three questionnaire items are: 1) I am satisfied with the offerings at this website. 2) I am satisfied with the purchases at this website. 3) I am satisfied with the products at this website.

7. E-Trust

E-trust is defined as customer willingness to accept vulnerability in an online transaction based in his/her positive expetation towards the products in the online store. In determining the parameters of this variable, it will be measured using items adapted by Chung and Shin (2010). The four questionnaire items are: 1) I trust the information that this website provides. 2) I trust the promise that this website makes. 3) I trust the products that this website provides. 4) I trust the delivery of products that this website makes.

\section{E-Commitment}

In the online context, e-commitment means the customer willingness to have a strong connection or have a strong bond with a certain website. In determining the parameters of this variable, it will be measured using items adapted by Chung and Shin (2010). The four questionnaire items are: 1) I feel this website as a friend. 2) I feel this website as a part of living. 3) I feel attached to this website. 4) I can feel a sense of belonging to this website that I transaction with. 
9. Positive E-WOM

Positive E-WOM refers to consumers' desire to share positive statements towards the website to other people. In determining the parameters of this variable, it will be measured using items adapted by Chung and Shin (2010). The three questionnaire items are: 1) I say positive thing about this website to other people. 2) I recommend this website to anyone who seeks my advice. 3) I say positive thing about products of this website.

SEM analysis is chosen to analyze the primary data (quantitative research analysis) to test and estimate a more complicated framework (Haryono \& Wardoyo, 2012). According to Hair, et al., (2010) SEM can be defined as a multivariate statistical analysis technique in which it is used to determine the structural relationships. According to Ghozali, Imam, and Fuad, (2008), SEM can be used to reduce the number of observed variables into a smaller number of latent variables. This test is carried out in order to measure the relationship within the latent variables and encompasses two components, which are a measurement model (the CFA) and a structural model (Ghozali, Imam, \& Fuad, 2008). As the fitness of the model is confirmed, hypothesis testing is conducted with the help of AMOS software. This tool is chosen to present, estimate, and assesses the specific model in an intuitive path diagram. In other words, SEM could estimate the path diagram of the relationship of each variable.

Table 1. Respondent Profile

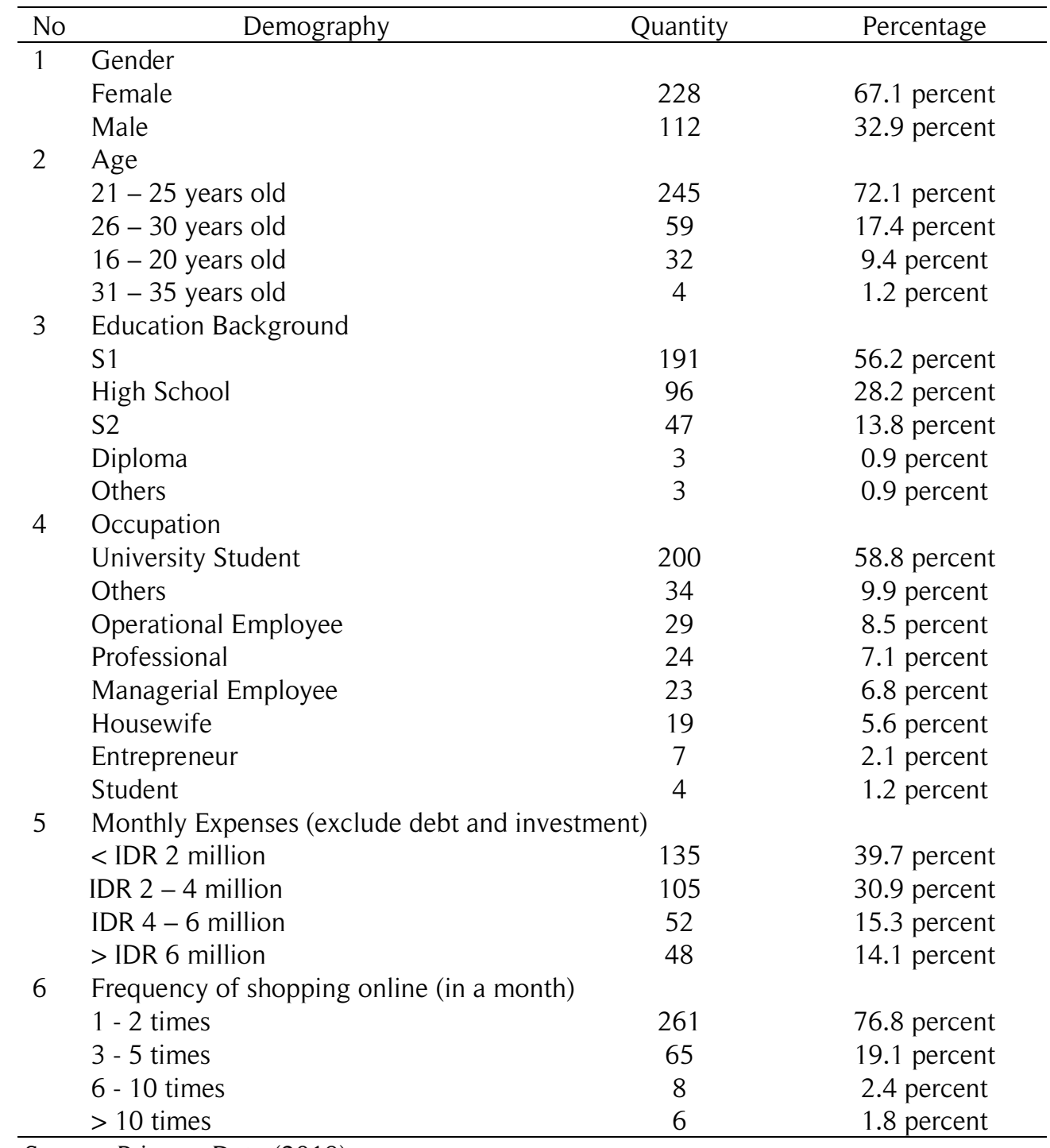

Source: Primary Data (2019) 
Table 1 presents respondents' characteristics. There are 351 respondents that have been submitted the questionnaires through online forms. However, due to the incomplete information, researcher only processed 340 questionnaires. It can be seen from the table above that the number of female respondents is bigger than male, with 67.1 percent of female and 32.9 percent of male. The respondents in this research are mostly between $21-25$ years old with 72.1 percent. University students, with 58.8 percent, dominate more than half of the whole respondents. There are 56.2 percent of the participants have undergraduate degree. Then, the expenses of the most respondents are in the range of less than $\mathrm{Rp} 2.000 .000,00$, with 39.7 percent. Mostly, there are 76.8 percent of respondents who spend 1 to 2 times per month in online shopping.

\section{Result and Discussion}

In this study, validity is calculated based on the loading factor value with the help of SPSS software. This software is able to measure the relationships within each variable. This method is an analytical technique to test whether the construct in the theory can be confirmed by the empirical data or not (Ghozali, 2011). The requirement to analyze using CFA can be seen from the value of KMO-MSA (Kaiser-Meyer-Olkin Measure of Sampling Adequacy). This analysis has to be conducted in order to measure the level of inter-correlation within the factor. The objective of this testing is to describe how good the variables can be used to measure the construct. The KMO-MSA value can be concluded as valid if the value is greater than 0.5 and it has a significance level of 0.05 (Hair, et al., 2010). In other words, the item is considered as valid and it can be continued if the value of loading factor from each construct is $\geq 0.5$, with the value of sig. $<0.05$.

From Tabel 2, it can be seen that KMO Measure of Sampling Adequacy value is 0.867 , which is greater than 0.5. The Chi-Square value on Barlett's Test is significant at the level of 0.000. It means that the model is valid and it can be brought to the next step.

Table 2. Barlett's and KMO of Sampling Adequancy

\begin{tabular}{lll}
\hline \multicolumn{2}{l}{ Kaiser-Meyer-Olkin Measure of Sampling Adequacy. } & \multicolumn{1}{c}{0.867} \\
\hline \multirow{3}{*}{ Barlett's Test of Sphericity } & Approx. Chi-Square & $5.924 \mathrm{E} 3$ \\
& df & 561 \\
& Sig. & 0.000 \\
\hline
\end{tabular}

Source: Primary Data (2019)

Table 3 shows that the values of each indicator that are more than 0.5 considered as good. Item SC1, SC4, and SD4 have a value of less than 0.5; therefore, those items are not included in the next analysis. Table above has 9 columns containing of 9 variables, which are: shopping convenience (SC), website design (SD), informativeness (IN), security (SEC), communication (COM), customer satisfaction (CS), e-trust (ET), e-commitment (EC), and positive E-WOM (WOM). From the result, it can be seen that the items are grouped based on each variable.

This research uses reliability testing with Cronbach's Alpha technique. If the value of construct reliability from each construct is about/more than 0.7 , it can be stated as reliable (Ghozali, Imam, \& Fuad, 2008). This test is conducted using the help of SPSS software.

Table 4 shows that the value of Cronbach's Alpha in each variable are exceeded 0.7, which means all the variables in the model are reliable. Researcher conducts the hypothesis testing by using Goodness of Fit Index to measure the goodness of the model proposed. The goodness of fit test shows the value of absolute fit measure (Chi-square, GTI, and RMSEA), incremental fir measure (NFI, TLI, and CFI), and parsimony fit measure (AGFI, PNFI and CMIN/DF). Table below shows the results of testing the goodness of fit model. 
Table 3. Rotated Component Matrix Result

\begin{tabular}{|c|c|c|c|c|c|c|c|c|c|}
\hline & \multicolumn{9}{|c|}{ Component } \\
\hline & 1 & 2 & 3 & 4 & 5 & 6 & 7 & 8 & 9 \\
\hline SC1 & & & & & & & & & 0.360 \\
\hline $\mathrm{SC} 2$ & & & & & & & & & 0.795 \\
\hline SC3 & & & & & & & & & 0.652 \\
\hline SC4 & & & & & & & & & 0.408 \\
\hline SD1 & & & & & & 0.789 & & & \\
\hline SD2 & & & & & & 0.675 & & & \\
\hline SD3 & & & & & & 0.805 & & & \\
\hline SD4 & & & & & & 0.499 & & & \\
\hline IN1 & & & & 0.771 & & & & & \\
\hline IN2 & & & & 0.784 & & & & & \\
\hline IN3 & & & & 0.676 & & & & & \\
\hline IN4 & & & & 0.765 & & & & & \\
\hline SEC1 & & & & & 0.633 & & & & \\
\hline SEC2 & & & & & 0.627 & & & & \\
\hline SEC3 & & & & & 0.806 & & & & \\
\hline SEC4 & & & & & 0.764 & & & & \\
\hline COM1 & 0.766 & & & & & & & & \\
\hline COM2 & 0.782 & & & & & & & & \\
\hline COM3 & 0.769 & & & & & & & & \\
\hline COM4 & 0.751 & & & & & & & & \\
\hline CS1 & & & & & & & & 0.665 & \\
\hline CS2 & & & & & & & & 0.656 & \\
\hline CS3 & & & & & & & & 0.673 & \\
\hline ET1 & & & 0.801 & & & & & & \\
\hline ET2 & & & 0.786 & & & & & & \\
\hline ET3 & & & 0.842 & & & & & & \\
\hline ET4 & & & 0.752 & & & & & & \\
\hline EC1 & & 0.788 & & & & & & & \\
\hline EC2 & & 0.808 & & & & & & & \\
\hline EC3 & & 0.846 & & & & & & & \\
\hline EC4 & & 0.861 & & & & & & & \\
\hline WOM1 & & & & & & & 0.738 & & \\
\hline WOM2 & & & & & & & 0.782 & & \\
\hline WOM3 & & & & & & & 0.605 & & \\
\hline
\end{tabular}

Source: Primary Data (2019).

Table 4. Reliability Testing Result

\begin{tabular}{lcc}
\hline \multicolumn{1}{c}{ Variable } & Cronbach's Alpha & Result \\
\hline Shopping Convenience & 0.870 & Reliable \\
Website Design & 0.894 & Reliable \\
Informativeness & 0.898 & Reliable \\
Security & 0.906 & Reliable \\
Communication & 0.935 & Reliable \\
Customer Satisfaction & 0.904 & Reliable \\
E-Trust & 0.954 & Reliable \\
E-Commitment & 0.964 & Reliable \\
Positive E-WOM & 0.935 & Reliable \\
\hline
\end{tabular}

Source: Primary Data (2019).

160 | (O) 2020 The Authors. Jurnal Siasat Bisnis. Published by The Management Development Centre, Department of Management, Faculty of Business \& Economics, Universitas Islam Indonesia 
Table 5. The Result of Goodness of Fit Model

\begin{tabular}{lccc}
\hline \multicolumn{1}{c}{ GOF } & Ideal Value & Actual Value & Category \\
\hline $\mathrm{X}^{2}$ (Chi-Square) & Small value & 695.954 & Marginal \\
GFI & $\geq 0.90$ & 0.887 & Marginal \\
RMSEA & $\leq 0.08$ & 0.048 & Good \\
NFI & $\geq 0.90$ & 0.874 & Marginal \\
TLI & $\geq 0.90$ & 0.929 & Good \\
CFI & $\geq 0.90$ & 0.940 & Good \\
AGFI & $\geq 0.90$ & 0.857 & Marginal \\
PNFI & $0.60-0.90$ & 0.740 & Good \\
CMIN/DF & $\leq 5.00$ & 1.766 & Good \\
\hline
\end{tabular}

Source: Primary Data (2019).

Based on the result above, it is known that the chi-square value is 695.954. This value is considered as very large because the value of chi-square is expected to be small. The GFI value is considered as good, with 0.887 . The value of RMSEA is less than 0.08 , with 0.048 . This number is considered as good. NFI testing result obtained a value of 0.874 . This value is considered as marginal. The result of CFI is good since the result is 0.940 . This value is exceeded the standard value which is 0.9. The AGFI test result obtained a value of 0.857 , which means that this value is categorized as marginal. The PNFI test result is 0.740 and it is categorized as good since it lies between $0.60-0.90$. The result of CMIN/DF test is considered as good since the value is not greater than 5.00. Based on the results, it can be concluded that the overall model is good.

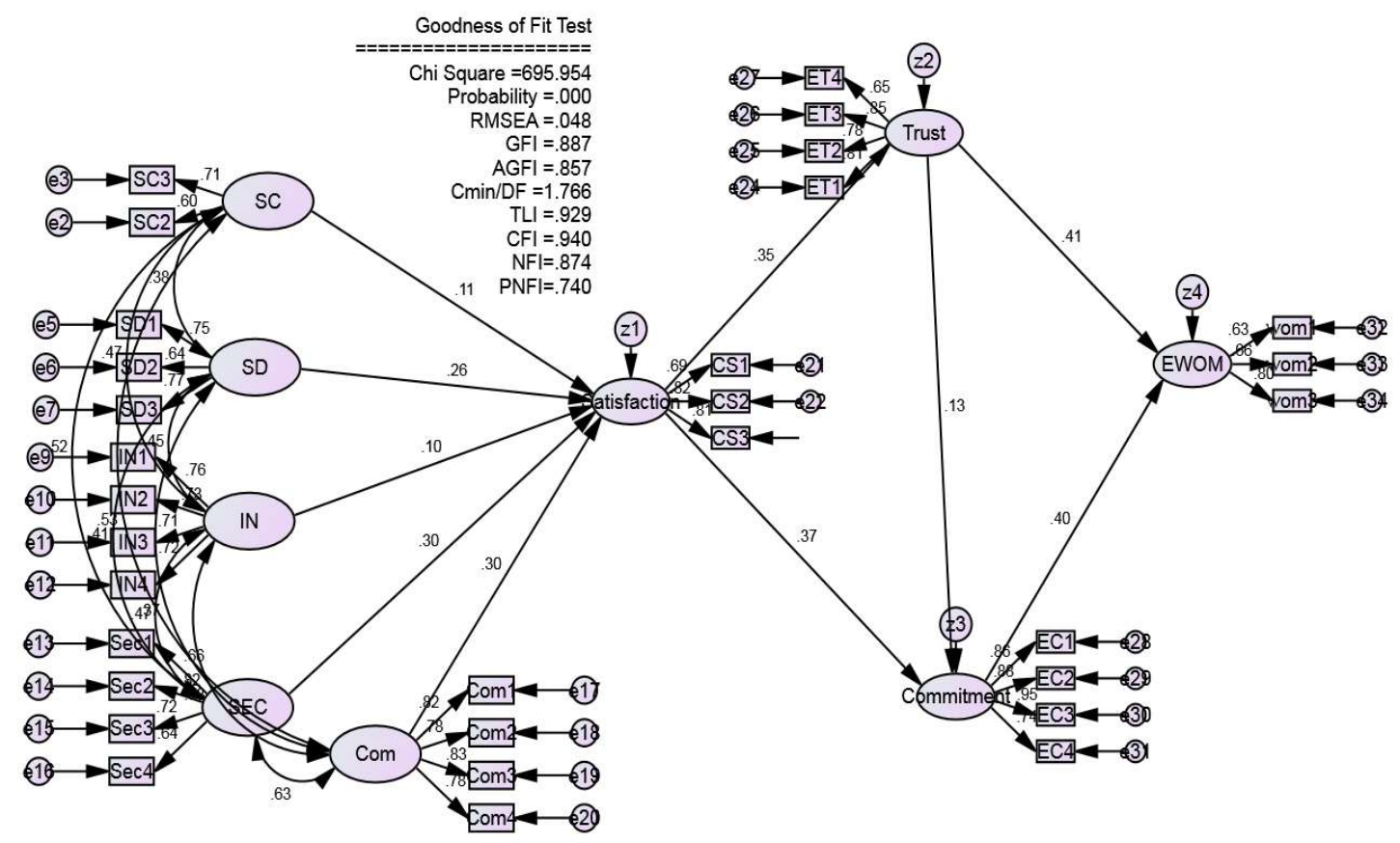

Figure 2. Research Model Result

From the figure above, it can be seen the ten hypotheses. There are eight hypotheses are supported and two hypotheses are not supported. The supported hypotheses are H2, H4, H5, H6, H7, $\mathrm{H} 8, \mathrm{H} 9$, and H10. The hypotheses that are not supported are $\mathrm{H} 1$ and H3. In Table 6, it shows the significance value of regression weight model that has been determined. The data was obtained from 340 respondents who have experienced in shopping through e-retailing in Indonesia. The results of hypothesis testing use a significance level of 5 percent or 0.05 with C.R. value of 1.96. 
Table 6. Hypothesis Testing Result

\begin{tabular}{lccccc}
\hline \multicolumn{1}{c}{ Variable } & Estimate & S.E. & C.R. & P value & Details \\
\hline Shopping Convenience $\rightarrow$ Customer Satisfaction & 0.136 & 0.089 & 1.534 & 0.125 & Not supported \\
Website Design $\rightarrow$ Customer Satisfaction & 0.230 & 0.053 & 4.326 & 0.000 & Supported \\
Informativeness $\rightarrow$ Customer Satisfaction & 0.093 & 0.057 & 1.643 & 0.100 & Not supported \\
Security $\rightarrow$ Customer Satisfaction & 0.316 & 0.080 & 3.952 & 0.000 & Supported \\
Communication $\rightarrow$ Customer Satisfaction & 0.227 & 0.053 & 4.259 & 0.000 & Supported \\
Customer Satisfaction $\rightarrow$ E-Trust & 0.405 & 0.075 & 5.392 & 0.000 & Supported \\
Customer Satisfaction $\rightarrow$ E-Commitment & 0.506 & 0.084 & 6.041 & 0.000 & Supported \\
E-Trust $\rightarrow$ E-Commitment & 0.148 & 0.065 & 2.271 & 0.000 & Supported \\
E-Trust $\rightarrow$ Positive E-WOM & 0.324 & 0.054 & 6.005 & 0.000 & Supported \\
E-Commitment $\rightarrow$ Positive E-WOM & 0.275 & 0.051 & 5.337 & 0.000 & Supported \\
\hline Sourc: Pri
\end{tabular}

Source: Primary Data (2019).

The first hypothesis test, the $p$ value is 0.125 and the C.R. value is 1.534 . The first hypothesis is not supported because the $p$ value is $0.125>0.05$. This result of the first hypothesis is not following the previous study conducted by Chung and Shin (2010), in which, shopping convenience is found to be positively and significantly affected by customer satisfaction. This matter due to the differences of perceiving risks of online shopping between South Korean and Indonesian users. According to Dharmesti and Nugroho (2012), good delivery management, security/privacy management, and fast response of the online store give a significant effect on online customer satisfaction. A study from Sfenrianto, Wijaya, and Wang (2018) also mentioned that convenience in online shopping did not give a significant effect on Indonesian customer satisfaction. This result also supported by Sfenrianto, et al. (2018), that shopping convenience has yet become the main driver of Indonesian customers shopping online. They stated that consumers in Indonesia are more driven by the low cost, fast delivery, and product availability.

At the second hypothesis test, the $p$ value is 0.000 and the C.R. value is 4.326 . This second hypothesis is supported because the $p$ value is $<0.05$. This result of the second hypothesis is following the result of Chung and Shin (2010), in which, website design is found to be positively and significantly affected customer satisfaction. A study from Park and Kim (2003) also mentioned that online users tend to be more satisfied to see the great appealing of a website. By this evidence, it is known that the better the design of a website, the more satisfied the customers will be. The features on a website will allow consumers to operate the website easily with the minimum effort. As a result of the test, it is known that consumers who are shopping online through e-retailing in Indonesia have great attention to the design of the websites. The better the quality of website design, included visual appealing, website appearance and fast response of the website, the consumer will feel more satisfied with the website. Consumers are likely to purchase from e-commerce where they can recognize the quality of the website.

In the third hypothesis test, the $p$ value is 0.100 and the C.R. value is 1.643 . This third hypothesis is not supported because the $\mathrm{P}$ value is greater than 0.05 . Therefore, it can be concluded that informativeness positively but not significantly affects customer satisfaction. This result is not following the previous study conducted by Chung and Shin (2010), where the informativeness is positively and significantly affects customer satisfaction. This matter due to the research settings and different research objects. This study was conducted in Indonesia in 2019 with different characteristics, both in terms of culture and different conditions, while the previous research was conducted in South Korea 
in 2010, while this. Chung and Shin (2010) mentioned that there are four items determining informativeness: rich information availability about features and quality of the products on the website, accurate information provided on the website, and peripheral information availability (payment, delivery, and return) on the website. The unsupported hypothesis indicates that the Indonesian online consumers did not get into the four indicators stated by Chung and Shin (2010).

Security has a positive effect on customer satisfaction. The $p$ value is 0.000 and the C.R. value is 3.952. This result shows that the $p$ value is $<0.05$. This result supports the previous study conducted by Chung and Shin (2010), where security is positively and significantly affects customer satisfaction. In other studies, it is also mentioned that the higher the security, the higher the satisfaction of its customers (Fullerton, 2011; Park \& Kim, 2003). They mentioned that customers do care about online security, reliability, and privacy policy of the websites.

Communication has a positive effect on customer satisfaction. As seen in Table 6, the p value is 0.000 and the C.R. value is 4.259. This fifth hypothesis is supported because the $P$ value is lower than 0.05. This result is following the previous study conducted by Chung and Shin (2010), in which, communication is positively and significantly affects customer satisfaction. In other literature, it is mentioned that the greater the communication, the greater the satisfaction of its customers (Fullerton, 2011; Murphy \& Sashi, 2018). They mentioned that communication from the seller has been recognized to have a positive significant effect on customer satisfaction. If the communication of the seller is poor, the satisfaction of online stores will be low as well.

In the sixth hypothesis test, customer satisfaction has a positive effect on e-trust with the $p$ value is 0.000 and the C.R. value is 5.392. The sixth hypothesis is supported because $p$ value $<0.05$. It means that customer satisfaction positively and significantly affects e-trust. Chung and Shin (2010) mentioned that customer satisfaction is positively and significantly affecting e-trust, which is in line with this finding. Choi, et al. (2007) mentioned that the higher the level of satisfaction, the higher the consumers' trust. Another study conducted by Horppu, et al. (2008) also believed that e-satisfaction positively and significantly influences e-trust. They empirically proved that there is a positive relationship between web website satisfaction and trust. Customer satisfaction is perceived as an essential concept as it seems to be a requirement for web website trust and loyalty. To increase Indonesian customer trust, e-retailers have to give them satisfaction first.

At the seventh hypothesis test, customer satisfaction has a positive effect on e-commitment. The $p$ value is 0.000 and the C.R. value is 6.041 . It can be said that customer satisfaction positively and significantly affects e-commitment. This finding is supported by the previous study conducted by Chung and Shin (2010), in which, customer satisfaction is positively and significantly affects e-commitment. Other studies also mentioned that there is a positive and significant relationship between customer satisfaction and commitment from the customer (Cater and Zabkar, 2008; Fullerton, 2011). They empirically proved that the relationship with a high satisfaction firm is more motivated to continue the relationship. Customers will feel satisfied when they have great overall experiences with certain providers, thus, they would like to feel that they should stay with that company because of the service that the company has done for them.

E-trust has a positive effect on e-commitment. As seen in table above, the $p$ value is 0.000 and the C.R. value is 2.271. This hypothesis is supported because the p value 0.000 is lower than 0.05 . It means that e-trust positively and significantly affects e-commitment. The greater the e-trust, the greater they are likely to commit to a relationship with the provider. Likewise, vice versa, when the etrust is low, the commitment from customers will be also low. This result is in line with a study conducted by Chung and Shin (2010), in which, e-trust is positively and significantly affects e-commitment. Another literature also mentioned that there is a positive and significant relationship between e-trust and commitment (Horppu, et al., 2008). They believed that trust is resulted from past activity and makes a customer think about the future and become committed to a certain company or brand.

E-trust has a positive effect on positive E-WOM. The estimated value $(\beta)$ is 0.148 and the C.R. value is 6.005 . This hypothesis is supported because the $p$ value $0.000<0.05$ It can be concluded that 
e-trust positively and significantly affects positive E-WOM. This result is following the previous study conducted by Chung and Shin (2010), in which, e-trust is positively and significantly affects positive E-WOM. Another piece of literature from Smith and Adviser-Menon (2002) mentioned that the customers are willing to read other people's reviews because there is increasing trust among the users. They believed that positive E-WOM is essential as the form of promotion where trust from customers plays a significant role in their choices. When there is high trust in a relationship, the customers will more likely to spread positive E-WOM to other customers. A website that has a good reputation will be easy to be recommended by its customers. Thus, it becomes important information for e-retailers to increase the positive EWOM by gaining trust from the customers.

The tenth hypothesis test, e-commitment has a positive effect on positive E-WOM. The $p$ value is 0.000 the C.R. value is 5.337. This hypothesis is supported because the $p$ value $0.000<0.05$. Therefore, it is said that e-commitment positively and significantly affects positive E-WOM. Chung and Shin (2010), mentioned that the e-commitment is positively and significantly affecting positive E-WOM, which is in accordance with this finding. When commitment to the company is high, positive word-of-mouth is more likely high as well. In other studies, it is mentioned that e-commitment has a positive effect on WOM (Tsao \& Hsieh, 2012). They believed that customers with high search intentions for information on the product in the online stores are more likely to have high intention to recommend to other people, compared to others who have lower search intentions.

\section{Conclusion}

The lack of studies in the relationship quality in Indonesia online shopping context is still investigated. There are a few findings on customer satisfaction as the antecedent of e-trust and e-commitment (Kim, 2002; Choi et al., 2007). Based on the results in this study, the researcher found the relationships between website characteristics (shopping convenience, website design, informativeness, security, and communication), customer satisfaction, e-trust, e-commitment, and positive E-WOM in e-retailing in Indonesia. These results provide critical implications to the retailers in Indonesia concerning which website characteristics that should be given more attention to improve customer satisfaction, e-trust, e-commitment, and e-WOM.

Shopping convenience and informativeness positively but not significantly influences customer satisfaction. This result is not following the previous study conducted by Chung and Shin (2010). Shopping convenience and informativeness have yet become the main driver of Indonesian customers to shopping online compared to South Korea internet users. This matter due to the perceived risks of internet shopping that are different between those countries. The consumer in Indonesia will feel more comfortable with a variety of features that make them enjoy shopping online, such as free shipping, price discount or attractive promos. Indonesian online consumers do not seem to try to spend the least amount of time shopping for daily necessities as well as South Korean customers. Consumers in Indonesia are more driven by the low cost, fast delivery, and product availability.

Improving the shopping convenience is not the only way that can be used as a prediction tool to recognize what features that customers value the most. A company can satisfy consumers by providing a website that provides good website design, security and privacy system, communication, attractive promos, and affordable prices. A good quality web design will make consumers interested in shopping. The company can provide a good web design by displaying a website that is easy to navigate and require less effort to be explored. The ease of information surely can help the customer to reduce risks and provide the relevant information when he or she needs it but it does not mean that it will increase customer satisfaction. Rather than investing in high information technology, companies might allocate the cost to other points. Creating the right user-friendly website allows the customer to access in a way that is most enjoyable for him/her. Security has a great influence on customer satisfaction. Providers need to focus on the customer privacy and payment system to reduce the risks, to create the mode of transactions as secure and trustworthy to overcome the fear of security. Eretailers should have control to secure the information regarding their customers so they will feel safer 
and more confident having transactions on the website. Communication influences customer satisfaction. This result gives a picture for e-retailer to establish an early warning system based on the customer feedback so that the company can take an appropriate remedial decision as an improvement. A company also can establish an appropriate customer relationship management system for handling complaints from customers and to encounter the problem as quickly as possible. E-retailers must be able to compete by providing a website that can always be trusted so that the quality of the website is well maintained. Maintaining a good reputation is one of the important things that e-retailers must recognize. It will be easier for the company in the future to set the strategy when they have gained trust from the customers. E-retailers should be able to present a good impression to their customers so that consumers are willing to commit to the company.

The limitations of this study are this study only analyzes 5 elements of website characteristics, which are shopping convenience, website design, informativeness, security, and communication. The respondents in this research are still less diverse based on their age, where most of the respondents who filled the questionnaires were at the age of $21-25$ years old, with 72.1 percent or 245 respondents and those respondents mostly come from Java Island, which can cause the uneven distribution. The next research is expected to discover another element of on-website characteristics other than 5 elements in this study, such as interactivity, innovativeness, and flow. Future study is expected to be filled by the representative of each age categories evenly. The questionnaire should not be dominated by certain age categories to represent the Indonesian population as a whole. Future study is expected to spread the questionnaire evenly across all islands in Indonesia. The questionnaire should not only dominate by people who domicile in Java Island. This action should be taken so that the sample can represent the population in Indonesia equally.

\section{References}

(2019). Top Sites in Indonesia. Alexa. Available at: https://www.alexa.com/topsites/countries/ID, accessed on January 3, 2019.

APJIII. (2018). Penetrasi pengguna internet Indonesia. Asosiasi Penyelenggara Jasa Internet Indonesia (APJII.) Available at https://apjiii.or.id., accessed on October 18, 2018.

Barlow, A. K., Noreen, Q. S., and Mannion, M. (2004). Developments in information and communication technologies for retail marketing channels. International Journal of Retail and Distribution Management, 32(3): 157-63.

Barreda, A. A., Bilgihan, A., Nusair, K., \& Okumus, F. (2015). Generating brand awareness in online social networks. Computers in Human Behavior, 50, 600-609.

Bolton, R. N., Parasuraman, A, Hoefnagels, A., Migchels N., Kabadayi, S., Gruber T., Loureiro, Y.K., and Solnet, D. (2013). Understanding Generation $Y$ and their use social media: a review and research agenda. Journal of Service Management, 24(3), 245-267.

Cater, B., and Zabkar, V. (2008). Antecedents and consequences of commitment in marketing research: The client's perspective. Industrial Marketing Management, 26(3): 245-54.

Choi, Y. G., Choi, D. C., and Lee, S. S. (2007). The effect of components of interactivity on satisfaction, trust, commitment, and loyalty in online community. Journal of Quality Management, 35(4): 123-39.

Chung, K.-H., and Shin, J.I. (2010). The antecedents and consequents of relationship quality in internet shopping. Asia Pacific Journal of Marketing, 22(4): 473-491.

Cooper, D., and Schindler, P. (2011). 'Business Research Methods' (11 ed.). New York, Avenue of the Americas: McGraw-Hill. 
Dharmesti, M.D.D and Nugroho, S. S. (2013). The Antecedents of online customer satisfaction and customer loyalty. Journal of Business and Retail Management Research, 7(2).

Fullerton, G. (2011). Creating advocates: The roles of satisfaction, trust, and commitment. Journal of Retailing and Consumer Services, 18(1): 92-100.

Ghozali, I. (2011). 'Aplikasi Analisis Multivariate dengan program IBM SPSS 19'. Semarang: Badan Penerbit Universitas Disponegoro.

Ghozali, Imam, and Fuad. (2008). 'Structural equation modeling; teori, konsep dan aplikasi dengan program Lisrel 8.80' (edisi 2). Semarang: Badan Penerbit Universitas Diponegoro.

Hair, J. F., Black, W., Babin, B., Anderson, R., and Tatham, R. (2010). 'Multivariate Data Analysis' (7th ed.). NJ: Pearson Prentice Hall.

Hajli, N., \& Sims, J. (2015). Social commerce: The transfer of power from sellers to buyers. Technological Forecasting and Social Change, 94, 350-358.

Haryono, S., and Wardoyo, P. (2012). 'Structural equation modeling: Untuk Penelitian Manajemen Menggunakan AMOS 18.00'. Bekasi: PT. Intermedia Personalia Utama.

Hennig-Thurau, T., Gwinner, K. P., Walsh, G., and Gremler, D. D. (2004). Electronic word-of-mouth via consumer-option platforms: What motivates consumers to articulate themselves on the internet? Journal of Interactive Marketing, 18(1): 38-52.

Hidayat, A., Saifullah, M., and Ishak, A. (2016). Determinants of satisfaction, trust, and loyalty of Indonesian E-Commerce customer. International Journal of Economics and Management 10: 151-166.

Horppu, M., Kuivalainen, O., and Ellonen, H. K. (2008). Online satisfaction, trust, and loyalty, and the impact of the offline parent brand. Journal of Product and Brand Management 17(6): 403-13.

Jiang, L., Yang, Z., and Jun, M. (2012). Measuring consumer perceptions of online shopping convenience. Journal of Service Management 24(2): 191-214.

Kim, S., and Park, H. (2013). Effects of characteristics of social commerce on consumers' trust and trust performance. International Journal of Information Management 33(2): 318-332.

Liu, X., He, M., Gao, F., and Xie, F. (2008). An empirical study of online shopping customer satisfaction in China: A holistic perspective. International Journal of Retail \& Distribution Management 36(11): 919-40.

Martinez, P. (2015). Customer loyalty: Exploring its antecedents from a green marketing perspective. International Journal of Cpntemporary Hospitality Management, 27(5), 896 - 917.

Mukherjee, A., and Nath, P. (2007). Role of electronic trust in online retailing: A re-examination of the commitment-trust theory. European Journal of Marketing 24(8): 1173-202.

Murphy, M and Sashi, C.M. (2017). Communication, interactivity, and satisfaction in B2B relationships. Industrial Marketing Management 68: 1-12.

Palmer, H. W. (2002). Web website usability, design, and performance metrics. Information Systems Reseach, 13(2), 151-167.

Park, C. H., and Kim, Y. G. (2003). Identifying key factors affecting consumer purchase behavior in an online shopping context. International Journal of Retail and Distribution Management 31(1): 16-29.

Sahadev, S., and Purani, K. (2008). Modeling the consequences of e-service quality. Marketing Intelligence and Planning, 26(6), 606-20.

166 (C) 2020 The Authors. Jurnal Siasat Bisnis. Published by The Management Development Centre, Department of Management, Faculty of Business \& Economics, Universitas Islam Indonesia 
Saleem, M.A., Zahra, S. and Yaseen, A (2017). Impact of service quality and trust on repurchase intentions - the case of Pakistan airline industry. Asia Pacific Journal of Marketing and Logistics, 29(5), 1136 - 1159.

Sfenrianto S., Wijaya, T., and Wang, G. (2018). Assessing the buyer trust and satisfaction factors in the e-marketplace. Journal of Theoretical and Applied Electronic Commerce Research 13(2).

Shankar, V., Smith, A. K., and Rangaswamy, A. (2003). Customer satisfaction and loyalty in online and offline environments. International Journal of Research in Marketing 20(2): 153-175.

Smith, D. N., and Adviser-Menon, S. (2002). Trust me, would I steer you wrong? The influence of peer recommendations within virtual communities.

Srinivansan, S., Anderson, R., and Ponnavolu, L. (2002). Customer loyalty in e-commerce: An exploration of its antecedents and consequences. Journal of Retailing 78: 41-50.

Szymanski, D., and Hise, R. T. (2000). E-satisfaction: An initial examination. Journal of Retailing 76(3): 309-322.

Tabrani, M., Amin, M. and Nizam, A. (2018). Trust, commitment, customer intimacy and customer loyalty in Islamic banking relationships. International Journal of Bank Marketing, 36(5), 823848.

Tarafdar, M., \& Zhang, J. J. (2005). Analyzing the Influence of Web Website Design Parameters on Web Website Usability. Information Resources Management Journal, 62-80.

Tsao, W. and Hsieh, M. (2012). Exploring how relationship quality influences positive eWOM: The importance of customer commitment. Total Quality Managemen,t 23(7): 821-835.

Wang, Y., Hernandez, M. D., and Minor, M. (2010). Web aesthetics effects on perceived online service quality and satisfaction in an e-tail environment: The moderating role of purchase task. Journal of Business Research, 63(9): 935-942.

Wulf, K. D., Schillewaert, N., Muylle, S., and Rangarajan, D. (2006). The role of pleasure in website success. Information and Management, 43(4): 434-450. 